\title{
PELAYANAN ADMINISTRASI DI KANTOR KELURAHAN
}

\author{
Shelly Oktafiyana SR, Gradila Apriani
}

\author{
Fakultas Ilmu Sosial dan Ilmu Politik Universitas Kapuas \\ Email: gradilaapriani@gmail.com
}

\begin{abstract}
Abstrak: Penelitian ini bertujuan untuk mengetahui pelaksanaan Pelayanan Administrasi pada Kantor Kelurahan Kapuas Kiri Hilir Kabupaten Sintang dan faktor-faktor yang mempengaruhinya, dan kegunaan dari penelitian ini diharapkan dapat memperkayakhasanah kajian tentang Kinerja Pemerintah Kelurahan, sertadiharapkan dapat memberikan kontribusi kepada Pemerintah Kabupaten Sintang dalam mewujudkan pelayanan Pemerintah Kelurahan yang baik, yang memenuhi aspirasi,tuntutan dan kebutuhan masyarakat. Hasil penelitian ini mengenai kualitas pelayanan publik pada Kantor Kelurahan Kapuas Kiri Hilir Kabupaten Sintang berdasarkan penelitian dengan menggunakan indikator standar prosedur pelayanan sudah sesuai dengan kebijakan penyelenggaraan administrasi terpadu. Berdasarkan penelitian dengan menggunakan indikator kompetensi petugas pelayanan perlu adanya peningkatan kualitas khususnya kompetensi dalam pengaplikasian IT. Berdasarkan dengan menggunakan indikator sarana dan prasarana pelayanan perlu adanya kebijakan dengan pengadaan fasilitas sarana prasarana guna menunjang kelancaran pelaksanaan kegiatan pelayanan. Berdasarkan hasil dari penelitian tersebut dapat disimpulkan bahwa kualitas pelayanan publik dalam bidang pelayanan administrasi kependudukan di Kantor Kelurahan Kapuas Kiri Hilir Kabupaten Sintang sudah cukup baik, untuk itu tentunya perlu adanya peningkatan kualitas pelayanan dalam penyelenggaraan pemerintahan.
\end{abstract}

Kata Kunci : Pelayanan, Administrasi, Pemerintah Kelurahan

Pelayanan publik yang dilaksanakan oleh aparatur pemerintah dalam melayani masyarakat merupakan keterlibatan dari fungsi aparatur sebagai pelayan masyarakat. Tugas utama dari aparatur pemerintah adalah untuk melayani masyarakat, maka baik ataupun buruknya pelayanan yang diberikan aparatur merupakan gambaran kinerja individu yang akan menentukan baik buruknya kinerja organisasi secara keseluruhan.

Pelayanan yang baik tidak terlepas dari peran pemberi layanan yaitu aparatur pemerintah. Penyelenggaraan tugas pokok dan fungsi sebagai aparatur pemerintah dalam memberikan pelayanan publik yang baik kepada masyarakat dituntut untuk memiliki sumber daya yang memadai, sikap aparatur pemerintah yang berdampak pada kualitas pelayanan yang diberikan kepada masyarakat pengguna jasa layanan. Dalam konteks pelayanan publik, pelayanan yang diberikan oleh aparatur pelayanan adalah untuk mempermudah urusan publik dengan memberikan pelayanan yang tidak berbelit-belit dengan prosedur yang panjang, mendahulukan kepentingan umum, mempersingkat waktu pelaksanaan urusan publik, dan memberikan kepuasan kepada masyarakat. Pelayanan publik pada hakikatnya adalah pemberian pelayanan prima kepada masyarakat yang merupakan perwujudan dan kewajiban aparatur negara sebagai abdi masyarakat.

Pemerintah Kelurahan sebagai wilayah administrasi publik yang merupakan ujung tombak pemerintahan, berkewajiban memenuhi kebutuhan dan hak bagi setiap warga negara dalam bentuk layanan sipil yang tersedia hanya di kantor pemerintahan. Pada kenyataanya unit kerja tersebut masih belum maksimal dalam melaksanakan tugas dan fungsinya terutama dalam memberikan pelayanan kepada masyarakat. Dalam kaitan pelayanan yang dilaksanakan oleh aparatur kelurahan merupakan pelaksanaan sistem administrasi pemerintahan melalui penyempurnaan sistem administrasi yang baik, tertib, serta teratur yang sesuai dengan aturan yang berlaku, diharapkan pelayanan publik dapat berjalan dengan efisien dan efektif.

Menurut Moenir (2010:27) pelayanan adalah "aktivitas yang dilakukan seseorang atau sekelompok orang dengan landasan faktor material melalui sistem, prosedur, dan metode tertentu dalam rangka memenuhi kebutuhan orang lain sesuai dengan haknya".

Dalam Undang-Undang Nomor 25 tahun 2009 Tentang Pelayanan Publik Pasal 1 ayat (1) 
disebutkan bahwa "Pelayanan publik adalah kegiatan atau rangkaian kegiatan dalam rangka pemenuhan kebutuhan pelayanan sesuai dengan peraturan perundang undangan bagisetiap warga negara dan penduduk atas barang, jasa, dan/atau pelayanan administratif yang disediakan oleh penyelenggara pelayanan publik".

Berdasarkan Peraturan Pemerintah Republik Indonesia Nomor 73 Tahun 2005 tentang Kelurahan pada Pasal 3 mengemukakan bahwa Kelurahan sebagaimana dimaksud dipimpin oleh Lurah yang berada di bawah dan bertanggungjawab kepada Bupati/Walikota melalui Camat. Dalam melaksanakan tugas pokok sebagaimana dimaksud dalam Pasal 4, Lurah mempunyai tugas: 1) Pelaksanaan kegiatan pemerintahan kelurahan; 2) Pemberdayaan masyarakat; 3) Pelayanan masyarakat; 4) Penyelenggaraan ketentraman dan ketertiban umum; 5) Pemeliharaan prasarana dan fasilitas pelayanan umum; dan 6) Pembinaan lembaga kemasyarakatan.

Menurut Hardiansyah (2011:23) jenis pelayanan umum atau publik yang diberikan pemerintah dibagi menjadi tiga kelompok, yaitu: 1) Pelayanan administrative; Pelayanan berupa penyediaan berbagai bentuk dokumen yang diperlukan oleh publik, misalnya : Pembuatan Kartu Tanda Penduduk (KTP), Sertifikat Tanah, Akta Kelahiran, Akta Kematian, Buku Kepemilikan Kendaraan Bermotor (BPKB), Surat Tanda Nomor Kendaraan (STNK), Izin Mendirikan Bangunan (IMB), Paspor, dan sebagainya. 2) Pelayanan Barang; Pelayanan yang menghasilkan berbagai bentuk/jenis barang yang menjadi kebutuhan publik, misalnya: jaringan telepon, penyediaan tenaga listrik, penyediaan air bersih. 3) Pelayanan Jasa; Pelayanan yang menghasilkan berbagai bentuk jasa yang dibutuhkan publik, misalnya: Pendidikan tinggi dan menengah, pemeliharaan kesehatan, penyelenggaraan transportasi, jasa pos, sanitasi lingkungan, persampahan, penanggulangan bencanan, pelayanan sosial.

Menurut Sinambela (2006:12) menyatakan bahwa "filosofi penting dari perilaku birokrasi adalah perbaikan dan peningkatan kompetensi aparatur. Kompetensi aparatur ditentukan oleh pengetahuan, keterampilan, pengalaman dan penguasan kerja yang menjadikan aparatur mampu mengembangkan perilaku birokrasi yang baik, sedangkan kompetensi aparatur yang memiliki pengetahuan yang rendah, tidak terampil, tidak berpengalaman dan tidak cakap mempengaruhi seseorang sulit mengembangkan perilaku birokrasinya".

Menurut Pasolong (2008:33) "Kompetensi berasal dari kata competent yang berarti mampu sepadan dengan kata ability atau kemampuan. Kompetensi ini berkaitan dengan potensi yang dimiliki individu sumber daya manusia dalam berperilaku dan bertindak untuk mencapai tujuannya".

Menurut Nurcholis (2007:17) "pemahaman mengenai kompetensi individu mempunyai keterkaitan dengan teori kerja, menjelaskan bahwa setiap pekerjaan memerlukan orang-orang yang berkompetensi dibidangnya. Artinya, antara aktivitas kerja dan kompetensi menjadi satu kesatuan dalam menghasilkan penilaian tentang pekerjaan".

Menurut Dwiyanto (2005:51) "Pelayanan publik yang profesional, artinya pelayanan publik yang dicirikan oleh adanya akuntabilitas dan responsibilitas dari pemberi layanan (aparatur pemerintah)". Dengan ciri sebagai berikut : 1) Efektif, lebih mengutamakan pada pencapaian apa yang menjadi tujuan dan sasaran; 2) Sederhana, mengandung arti prosedur/tata cara pelayanan diselenggarakan secara mudah,cepat, tepat, tidak berbelit-belit, mudah dipahami dan mudah dilaksanakan oleh masyarakat yang meminta pelayanan; 3) Kejelasan dan kepastian (transparan), mengandung akan arti adanya kejelasan dan kepastian; 4) Keterbukaan, mengandung arti prosedur atau tata cara persyaratan, satuan kerja/ pejabat penanggung jawab pemberi pelayanan, waktu penyelesaian, rincian waktu/tarif serta halhal lain yang berkaitan dengan proses pelayanan wajib diinformasikan secara terbuka agar mudah diketahui dan dipahami oleh masyarakat, baik diminta maupun tidak diminta; 5) Efisiensi; 6) Ketepatan waktu, kriteria ini mengandung arti pelaksanaan pelayanan masyarakat dapat diselesaikan dalam kurun waktu yang telah ditentukan; 7) Responsif, lebih mengarah pada daya tanggap dan cepat menanggapi apa yang menjadi masalah, kebutuhan dan aspirasi masyarakat yang dilayani; 8) Adaptif, cepat menyesuaikan terhadap apa yang menjadi tuntutan, keinginan dan aspirasi masyarakat yang dilayani yang senantiasa mengalami tumbuh kembang.

Selanjutnya menurut Moenir (2010:61) mengatakan bahwa bentuk pelayanan terdapat dua macam, yaitu: 1) Pelayanan Dengan Lisan; Pelayanan dengan lisan ini dilakukan oleh petugaspetugas bidang hubungan masyarakat (Humas), 
bidang layanan informasi dan bidang-bidang lain yang tugasnya memberikan penjelasan atau keterangan kepada masyarakat mengenai berbagai fasilitas layanan yang tersedia. Agar layanan lisan berhasil sesuai dengan yang diharapkan, ada syaratsyarat yang harus dipenuhi oleh pelaku pelayanan yaitu: a. Memahami benar masalah-masalah yang termaksud dalam bidang tugasnya. b. Mampu memberikan penjelasan apa-apa saja yang perlu dengan lancar singkat tetapi cukup jelas sehingga memuaskan bagi mereka yang ingin memperoleh penjelasan mengenai suatu informasi. c. Bertingkah laku sopan dan ramah tamah. Meski dalam keadaan sepi tidak berbincang dan bercanda dengan sesama pegawai, karena menimbulkan kesan tidak disiplin dan melalaikan tugas. 2) Pelayanan Melalui Tulisan; Dalam bentuk tulisan layanan yang diberikan dapat berupa pemberian penjelasan kepada masyarakat dengan penerangannya berupa tulisan suatu informasi mengenai hal atau masalah yang sering terjadi. Pelayanan melalui tulisan terdiri dari tiga macam, yaitu: a. Layanan yang berupa petunjuk, informasi dan sejenis yang ditunjukkan pada orang-orang yang berkepentingan, agar memudahkan mereka dalam berurusan dengan instansi atau lembaga. b. Pelayanan berupa reaksi tertulis atau permohonan, laporan, keluhan, pemberitahuan dan lain sebagainya. c. Pelayanan dalam bentuk perbuatan adalah pelayanan yang diberikan dalam bentuk perbuatan atau hasil perbuatan, bukan sekedar kesanggupan dan penjelasan secara lisan.

Menurut Sedarmayanti (2011:83) terdapat beberapa prinsip pokok yang harus dipahami oleh aparat birokrasi publik, maka prinsip-prinsip dalam pelayanan publik antara lain: 1) Prinsip Aksestabilitas, dimana setiap jenis pelayanan harus dapat dijangkau secara mudah oleh setiap pengguna pelayanan (misal: masalah tempat, jarak dan prosedur pelayanan), 2) Prinsip Kontinuitas, yaitu bahwa setiap jenis pelayanan harus secara terus menerus tersedia bagi masyarakat dengan kepastian dan kejelasan ketentuan yang berlaku bagi proses pelayanan tersebut. 3) Prinsip Teknikalitas, yaitu bahwa setiap jenis pelayanan proses pelayanannya harus ditangani oleh aparat yang benar-benar memahami secara teknis pelayanan tersebut berdasarkan kejelasan, ketepatan dan kemantapan sistem, prosedur dan instrumen pelayanan. 4) Prinsip Profitabilitas, yaitu bahwa proses pelayanan pada akhirnya haru dapat dilaksanakan secara efektif dan efesien serta memberikan keuntungan ekonomis dan sosial baik bagi pemerintah maupun bagi masyarakat luas. 5) Prinsip Akuntabilitas, yaitu bahwa proses, produk dan mutu pelayanan yang telah diberikan harus dapat dipertanggung-jawabkan kepada masyarakat karena aparat pemerintah itu pada hakekatnya mempunyai tugas memberikan pelayanan yang sebaik-baiknya kepada masyarakat.

Berdasarkan Undang-undang Nomor 25 Tahun 2009 tentang Pelayanan Publik, dalam pasal 1 butir (1) disebutkan bahwa "Pelayanan publik adalahkegiatan atau rangkaian kegiatan dalam rangka pemenuhan kebutuhan pelayanan sesuai dengan peraturan perundang-undangan bagi setiap warga negara danpenduduk atas barang, jasa, dan/ atau pelayanan administratif yang disediakan oleh penyelenggara pelayanan publik".

Menurut Monier (2010:67) Sarana pelayanan diartikan yaitu "segala jenis peralatan, perlengkapan kerja dan fasilitas lain yang berfungsi sebagai alat utama atau pembantu dalam rangka pelaksanaan pekerjaan, dan juga berfungsi sosial dalam rangka kepentingan orang-orang yang sedang berhubungan dengan organisasi kerja".

Lebih lanjut menurut Monier (2010:68) mengemukakan beberapa fungsi sarana pelayanan antara lain ; 1) Mempercepat proses pelaksanaan pekerjaan, sehingga dapat menghemat waktu. 2) Meningkatkan produktifitas, baik barang dan jasa. 3) Kualitas produk yang lebih dan terjamin. 4) Ketetapan susunan dan stabilitas ukuran terjamin.5) Lebih mudah/sederhana dalam gerak para pelakunya. 6) Menimbulkan rasa kenyamanan bagi orang-orang yang berkepentingan sehingga dapat mengurangi sifat emosional mereka.

\section{METODE PENELITIAN}

Pelayanan Administrasi di Kantor Kelurahan Kapuas Kiri Hilir Kabupaten Sintang, dengan jenis penelitian ini berbentuk penelitian deskriptif kualitatif. Menurut Moleong (2014:4) "mendefinisikan penelitian kualitatif sebagai prosedur penelitian yang menghasilkan data deskriptif berupa kata-kata tertulis atau lisan dari orang-orang dan perilaku yang diamati dari fenomena yang terjadi".

Lebih lanjut menurut Moleong (2014:6) mengemukakan bahwa "penelitian deskriptif adalah Dalam penelitian diskriptif ini, sifatnya menggali, menyusuri, menentukan fakta-fakta, masalah atau kendala yang mungkin dihadapi sekaligus memberikan penjelasan.

Metode kualitatif adalah suatu konsep keseluruhan untuk mengungkapkan rahasia sesuatu 
yang dilakukan dengan menghimpun data dalam keadaan sewajarnya, dengan menggunakan cara kerja yang sistematik, terarah dan dapat dipertanggung jawabkan untuk memecahkan suatu masalah dengan cara memaparkan, menafsirkan, dan menganalisa, serta menginterpretasikan data yang ada. Sedangkan data yang dikumpulkan dalam penelitian ini berupa data kata-kata dan gambaran. Teknik pengumpulan data yang digunakan yaitu wawancara, observasi dan studi dokumentasi.

\section{HASIL PENELITIAN DAN PEMBAHASAN Standar Pelayanan}

Pelayanan kepada masyarakat menjadi salah satu aspek paling penting di dalam pelaksanaan fungsi pemerintahan. Pemerintah berusaha memberikan pelayanan yang terbaik sebagai implikasi dari fungsi aparatur negara dimana pemerintah adalah pelayan masyarakat terutama yang berkaitan dengan pelaksanaan tugas-tugas umum pemerintahan dengan membentuk sistem administrasi pemerintahan yang dimulai dari pemerintahan tertinggi (tingkat pusat) sampai kepemerintahan terendah (desa/ kelurahan) agar dapat memberikan pelayanan yang optimal kepada masyarakat.

Dalam rangka mewujudkan pelaksanaan reformasi birokrasi, setiap penyelenggara pelayanan publik wajib menetapkan Standar Operasional Prosedur (SOP) yang bertujuan untuk meningkatkan kualitas pelayanan publik dan juga sebagai acuan dalam penilaian operasional kinerja dan kualitas penyelenggaraan pelayanan.

Berdasarkan Undang-Undang Nomor 23 Tahun 2014 tentang Pemerintahan Daerah dan Peraturan Pemerintah Nomor 17 Tahun 2018 tentang Kecamatan, kedudukan Kelurahan bukan lagi merupakan satuan kerja perangkat daerah, namun sebagai perangkat Kecamatan. Lurah selaku perangkat Kecamatan melaksanakan kewenangan pemerintahan dari dua sumber yakni, bidang kewenangan dalam lingkup urusan pemerintahan umum dan tugas umum pemerintahan.

Pelayanan administrasi publik maupun administrasi Pemerintah Kelurahan sebagai perangkat daerah pemerintahan Kabupaten dalam wilayah kerja kecamatan tentunya mengikuti acuan pedoman teknis yang ditetapkan berdasarkan peraturan Bupati. Berikut penulis tampilkan data dalam bentuk tabel mengenai jenis administrasi Pemerintah Kelurahan Kapuas Kiri Hilir, yaitu sebagai berikut:

Tabel 1. Jenis dan Bentuk Administrasi Pemerintahan Kelurahan Kapuas Kiri Hilir

\begin{tabular}{|c|l|l}
\hline No & Jenis Administrasi & \multicolumn{1}{c}{ Bentuk Administrasi } \\
\hline 1 & Administrasi Umum & $\begin{array}{l}\text { a) Buku Data Keputusan Lurah; } \\
\text { b) Buku Data Inventaris Kelurahan; } \\
\text { c) Buku Data Aparat Kelurahan; } \\
\text { d) Buku Data Tanah di Kelurahan; } \\
\text { e) Buku Data Agenda Masuk dan Keluar; } \\
\text { f) Buku Ekspedisi. }\end{array}$ \\
\hline 2 & Administrasi Penduduk & $\begin{array}{l}\text { a) Buku Data Induk Penduduk Kelurahan; } \\
\text { b)Buku Data Mutasi Penduduk Kelurahan; } \\
\text { c) Buku Data Rekapitulasi Jumlah Penduduk Akhir Bulan; } \\
\text { d)Buku Data Penduduk Sementara. }\end{array}$ \\
\hline 3 & Administrasi Keuangan & $\begin{array}{l}\text { a) Buku Kas Umum; } \\
\text { b)Buku Kas Pembantu Perincian Objek Penerimaan; } \\
\text { c) Buku Kas Pembantu Perincian Objek Pegeluaran; } \\
\text { d)Buku Kas Harian Pembantu; } \\
\text { e) Buku lainnya sesuai dengan ketentuan yang berlaku. }\end{array}$ \\
\hline 4 & Administrasi & $\begin{array}{l}\text { a) Buku Rencana Pembangunan; } \\
\text { b)Buku Kegiatan Pembangunan; } \\
\text { c) Buku Inventaris Proyek; } \\
\text { d) Buku Kader-kader Pembangunan. }\end{array}$ \\
\hline 5 & Administrasi Lainnya & $\begin{array}{l}\text { a) Buku Data Pengurus dan Anggota Lembaga } \\
\text { Kemasyarakatan; } \\
\text { b)Buku Register; } \\
\text { c) Buku Monografi Kelurahan. }\end{array}$ \\
\hline
\end{tabular}


116. Fokus, Volume 19, Nomor 1, Maret 2021, hlm. 112 - 120

Penetapan standar kerja dalam pelayanan yaitu mengatur tentang pembagian dan tata kerja Aparatur Pemerintah Kelurahan yang bertujuan untuk meningkatkan kualitas serta efektifitas pelaksanaan tugas pokok, fungsi dan kewenangan
Aparatur dalam pelayanan. Berikut penulis tampilkan data dalam bentuk tabel mengenai pelayanan administrasi pada bidang tugas pemerintahan, yaitu sebagai berikut:

Tabel 2. Jenis dan Persyaratan pelayanan Administrasi Pada Bidang Tugas Pemerintahan Kelurahan Kapuas Kiri Hilir Tahun 2020

\begin{tabular}{|c|c|c|c|}
\hline No & Bidang Tugas & Jenis Pelayanan & Persyaratan \\
\hline 1 & Pemerintahan & $\begin{array}{l}\text { Surat Keterangan } \\
\text { Perpanjangan KTP }\end{array}$ & $\begin{array}{l}\text { a) Surat Pengantar RT/RW } \\
\text { b)KTP (Asli) } \\
\text { c)FC KK } \\
\text { d)Pas Foto } 3 \text { x } 4 \text { (3 lembar) } \\
\text { e)FC Lunas PBB }\end{array}$ \\
\hline 2 & Pemerintahan & $\begin{array}{l}\text { Surat Keterangan Pembuatan } \\
\text { KTP Pemula }\end{array}$ & $\begin{array}{l}\text { a) Surat Pengantar RT/RW } \\
\text { b)FC KK } \\
\text { c) Pas Foto } 3 \times 4 \text { ( } 3 \text { lembar) } \\
\text { d)FC Lunas PBB }\end{array}$ \\
\hline 3 & Pemerintahan & $\begin{array}{l}\text { Surat Keterangan Pindah } \\
\text { Penduduk }\end{array}$ & $\begin{array}{l}\text { a) Surat Pengantar RT/RW } \\
\text { b)KTP (Asli) } \\
\text { c) KK (Asli) }\end{array}$ \\
\hline 4 & Pemerintahan & $\begin{array}{l}\text { Surat Keterangan Masuk } \\
\text { Penduduk }\end{array}$ & $\begin{array}{l}\text { a) Surat Pengantar RT/RW } \\
\text { b) Surat Keterangan Pindah dari } \\
\text { daerah Asal }\end{array}$ \\
\hline 5 & Pemerintahan & Pengajuan Akte Kelahiran & $\begin{array}{l}\text { a) Surat Pengantar RT/RW } \\
\text { b)FC KTP + KK } \\
\text { c)FC Surat Nikah } \\
\text { d)FC Surat Ket. Lahir dari } \\
\text { Bidan/Rmh Sakit } \\
\text { e)FC Lunas PBB }\end{array}$ \\
\hline 6 & Pemerintahan & Surat Keterangan Kematian & $\begin{array}{l}\text { a) Surat Pengantar RT/RW } \\
\text { b)FC KTP yang meninggal } \\
\text { c) Surat Ket. Kematian dari RS }\end{array}$ \\
\hline 7 & Pemerintahan & $\begin{array}{l}\text { Legalisasi Perubahan Data } \\
\text { KK }\end{array}$ & $\begin{array}{l}\text { a) Surat Pengantar RT/RW } \\
\text { b)KK ASLI }\end{array}$ \\
\hline 8 & Pemerintahan & $\begin{array}{l}\text { Surat Keterangan Riwayat } \\
\text { Tanah }\end{array}$ & $\begin{array}{l}\text { a) Surat Pengantar RT/RW } \\
\text { b)FC KTP Pemohon } \\
\text { c)FC Akta Jual Beli } \\
\text { d)FC Bukti Lunas PBB }\end{array}$ \\
\hline
\end{tabular}

Sumber : Kantor Kelurahan Kapuas Kiri Hilir, 2020 
Penetapan standar pelayanan sebagai pedoman teknis dalam pelaksanaan administrasi kelurahan untuk melaksanakan program atau kegiatan yang diharapkan dapat terwujudnya komitmen atas kinerja terukur berdasarkan tugas, fungsi, dan wewenang serta sumber daya yang tersedia. Lebih lanjut berdasarkan dari keterangan Sekretaris Kelurahan Kapuas Kiri Hilir, penulis tampilkan data dalam bentuk gambar mengenai mekanisme alur pelayanan pada Kantor Kelurahan Kapuas Kiri Hilir, yaitu sebagai berikut :

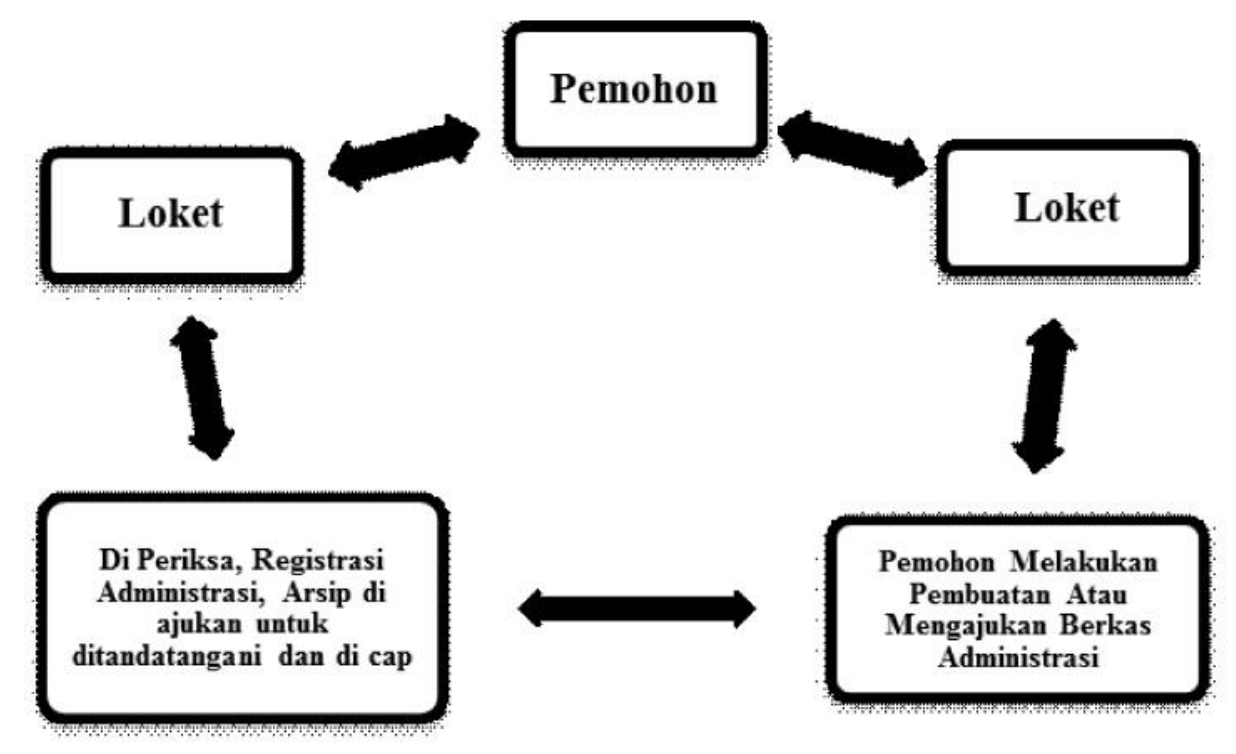

Berdasarkan data gambar tersebut menjelaskan bahwa dalam penyelenggaraan pelayanan public di Kantor Kelurahan Kapuas Kiri Hilir menggunakan mekanisme dengan pelayanan satu pintu, dimana pemohon atau masyarakat yang ingin mengurus administrasi kependudukannya, dengan datang langsung pada loket pelayanan yang sudah disiapkan untukmelakukan pembuatan atau permohonan administrasi yang diperlukan, kemudian petugas pelayanan akan melakukan pemeriksaan registrasi administrasi arsip, yang diajukan untuk ditanda tangani, setelah selesai ditandatangani kemudiandicap sebagai tanda legalitas dokumen, kemudian berkas diserahkan ke pemohon.

\section{Kompetensi Petugas Pelayanan}

Efektifitas penyelenggaraan pelayanan publik, sangat tergantung dari kinerja aparatur atau pegawai pemerintah termasuk dalam hal ini pegawai yang ditempat-tugaskan pada Kantor Kelurahan Kapuas Kiri Hilir. Berdasarkan kedudukan dan tugas Kelurahan yaitu sebagai perangkat Kecamatan yang mempunyai tugas dan fungsi melaksanakan penyelenggaraan pemerintahan diwilayah Kelurahan yang dipimpin seorang Lurah, tentunya dalam melaksanakan tugas penyelenggaraan kegiatan pemerintah yang diberikan oleh Camat, Lurah dibantu oleh perangkat Kelurahan, oleh karena itu maka menjadi sangat penting untuk mengetahui kompetensi yang dimiliki pegawai yang mencakup penguasaan pengetahuan, keterampilan, dan wawasan yang diperoleh melalui pendidikan, latihan, belajar dan pengalaman yang dibutuhkan demi tercapainya pelaksanaan pelayanan yang efektif kepada masyarakat.

Dalam upaya agar dapat menyelenggarakan pelayanan publik yang efektif, selain pentingnya peran dari perangkat petugas pelayanan dan tentunya juga harus ada dukungan dalam pengelolaan tata kerja yang baik dari seluruh unit pekerjaan pada masing-masing bidang tugas. Hanya saja kebijakan dalam penempatan pegawai tersebut merupakan wawenang dari Camat.

Kompetensi pegawai yang ada dirasa sudah cukup memadai, hal tersebut dapat dilihat dari tingkat pendidikan dan pengalaman aparatur yang ditempatkan pada tiap bidang tugasnya masing-masing. Lebih lanjut agar dapat melihat dan mudah memahaminya penulis tampilkan data daftar nama pegawai berdasarkan, pangkat dan golongan ruang, jabatan dan tingkat pendidikan dalam bentuk tabel, berikut di bawah ini: 
118. Fokus, Volume 19, Nomor 1, Maret 2021, hlm. 112 - 120

Tabel 3. Daftar Nama Aparatur Berdasarkan Pangkat Golongan Ruang, Jabatan Dan Pendidikan Kelurahan Kapuas Kiri Hilir Tahun2019

\begin{tabular}{|c|l|c|l|c|}
\hline No & \multicolumn{1}{|c|}{ Nama } & Gol & \multicolumn{1}{|c|}{ Jabatan } & Pendidikan \\
\hline 1 & M. Agus,S.Sos & $\begin{array}{r}\text { Penata TK.1 } \\
\text { (III/d) }\end{array}$ & Lurah & S.1 \\
\hline 2 & Syamsul Bahri & $\begin{array}{r}\text { Penata } \\
\text { (III/C) }\end{array}$ & Sekretaris & SMA \\
\hline 3 & Supriyono & $\begin{array}{r}\text { Penata Muda } \\
\text { Tk.I (III/c) }\end{array}$ & $\begin{array}{l}\text { Kasi Pemberdayaan dan } \\
\text { Kesejahteraan Masyarakat }\end{array}$ & SMA \\
\hline 4 & Novianto,S.Sos & $\begin{array}{r}\text { Penata Muda } \\
\text { Tk.I (III/b) }\end{array}$ & $\begin{array}{l}\text { Kasi Ekonomi dan } \\
\text { Pembangunan }\end{array}$ & S.1 \\
\hline 5 & Maskur Abdul Manan & $\begin{array}{r}\text { Penata Muda } \\
\text { Tk.I(III/b) }\end{array}$ & $\begin{array}{l}\text { Kasi Pemerintahan, } \\
\text { Ketertiban, dan Pelayanan } \\
\text { Umum }\end{array}$ & SMA \\
\hline 6 & Asriyansyah & $\begin{array}{r}\text { Pengatur Muda } \\
\text { (II/b) }\end{array}$ & $\begin{array}{l}\text { Staf Pemerintahan, } \\
\text { Ketertiban, dan Pelayanan } \\
\text { Umum }\end{array}$ & SMA \\
\hline 7 & $\begin{array}{l}\text { Mauludin } \\
\text { Hidayatullah,S.Sos }\end{array}$ & $\begin{array}{r}\text { Penata Muda } \\
\text { (III/a) }\end{array}$ & Staf Fungsional Umum & SMK \\
\hline
\end{tabular}

Sumber: Kantor Kelurahan Kapuas Kiri Hilir, 2020

Pada masa saat ini aparatur pemerintah wajib memiliki kompetensi pada bidang IT yang merupakan kebutuhan dengan kebijakan pemerintah pusat dalam penyelenggaraan pelayanan berbasis elektronik yaitu proses pelayanan yang dilakukan dengan menggunakan teknologi informasi. Sebab itu sebelum ditetapkannya kebijakan tersebut maka perlu adanya persiapan yaitu mengenai beberapa pelatihan yang diikuti meliputi :Pelatihan komputer, Pelatihan dalam pembuatan arsip, Penyuluhan tenaga kerja pegawai Kelurahan, dan Pembinaan pelayanan kemasyarakatan.

Terdapat tiga tingkat kompetensi yang harus dimiliki oleh aparatur pemerintah guna dalam melaksanakan tugas dan fungsinya dalam penyelenggaraan pemerintah, yaitu: 1) Kemampuan dasar, yaitu meliputi pengetahuan tentang regulasi tentang dasar-dasar pemerintahan, dan pengetahuan tentang tugas pokok dan fungsi. 2) Kemampuan manajemen, yaitu meliputi manajamen SDM, manajemen pelayanan publik, manajamen asset, dan managemen keuangan. 3) Kemampuan teknis, yaitu meliputi penyusunan administrasi pemerintahan, penyusunan perencanaan pembangunan, penyusunan anggaran, penyusunan peraturan, dan pelayanan publik.

Jika aparatur memiliki ketiga kompetensi tersebut, maka dalam pelaksanaan tugas pada bidang jabatannya dapat berjalan dengan baik, hanya saja dalam peningkatan kompetensi tersebut dalam pelatihan-pelatihan pengembangannya yang diselenggarakan oleh pemerintah pusat maupun daerah, jarang sekali aparatur yang bertugas di Kelurahan untuk mendapatkan kesempatan ditunjuk mengikuti kegiatan tersebut, padahal sebagai ujung tombak pelaksanaan kebijakan pemerintah maksud dari penyelenggaraan pelayanan di Kelurahan dan Kecamatan berbasis elektronik adalah untuk mewujudkan layanan publik kepada masyarakat yang efektif, efisien, dan akuntabel serta menjadikan Kelurahan dan Kecamatan sebagai pusat dan simpul seluruh jenis pelayanan administratif kepada masyarakat.

\section{Sarana dan Prasarana Pelayanan}

Sarana dan prasarana adalah merupakan seperangkat alat yang digunakan dalam suatu proses kegiatan baik alat tersebut adalah merupakan peralatan pembantu maupun peralatan utama, yang keduanya berfungsi untuk melancarkan dan memudahkan pelaksanaan fungsi kebijakan dan program-program yang dijalankan oleh aparatur pelaksana.

Salah satu hal yang dapat menciptakan pelayanan yang efektif adalah mengenai sarana dan prasarana yang ada disebuah organisasi, menyangkut pada pemberian pelayanan kepada masyarakat. Karena sebagai penyedia pelayanan, harus selalu memperhatikan sarana dan prasarana untuk suatu kegiatan pelayanan kepada masyarakat pengguna jasa. Karena ketersediaan sarana dan prasarana yang baik, akan mempengaruhi persepsi masyarakat terhadap kualitas pelayanan. 
Shelly Oktafiyana SR, Gradila Apriani, Pelayanan Administrasi Di Kantor Kelurahan $\mathbf{S}$

Tabel 4. Keadaan Sarana dan Prasarana Kantor Kantor Kelurahan Kapuas Kiri Hilir Tahun 2020

\begin{tabular}{|c|c|c|c|}
\hline No & Jenis Sarana dan Prasarana & Jumlah & Keterangan \\
\hline 1 & Meja & 8 & Baik \\
\hline 2 & Kursi & 16 & Baik \\
\hline 3 & Lemari Arsip & 3 & Baik \\
\hline 4 & Laptop & 2 & Baik \\
\hline 5 & Printer & 2 & Baik \\
\hline 6 & Tv & 1 & Baik \\
\hline 7 & Kipas Angin & 2 & Baik \\
\hline 8 & Kendaraan Dinas (Motor) & 1 & Baik \\
\hline 9 & Papan Informasi & 1 & Baik \\
\hline 10 & Kotak Pengaduan & & Baik \\
\hline
\end{tabular}

Sumber : Kantor Kelurahan Kapuas Kiri Hilir, 2020

Keadaan sarana pelayanan Kantor Kelurahan Kapuas Kiri Hilir masih kurang memadai, yang seharusnya disediakan fasilitas meja khusus untuk pemohon sehingga dapat dimudahkan menulis dan menyusun berkas kelengkapan administrasi. Selanjutnya dimana masih kurangnya jumlah kursi tunggu, yang mengakibatkan jika terjadi banyak antrian maka masyarakat harus menunggu diluar Kantor.

Fasilitas sarana dan prasarana yang tersedia di Kantor Kelurahan Kapuas Kiri Hilir memang masih belum sepenuhnya memadai terutama fasilitas yang tersedia pada ruang tunggu, masih minim dan dengan ukuran ruangan yang masih sangat terbatas dimana sudah berusaha dianggarkan untuk masuk pada kegiatan pengadaan barang namun sampai saat ini belum terealisasi karena anggaran yang terbatas sehingga digunakan untuk kegiatan yang memang sangat dibutuhkan.

Berdasarkan hasil observasi dari penelitian yang penulis lakukan tersebut, masih diperlukan adanya penambahan atau pengadaan meja dan kursi, penataan ruang tunggu yang lebih baik, menjaga kebersihan kantor, penyediaan tempat sampah, memberikan tanda tanda larangan untuk tidak merokok didalam ruangan, terlebih khusus kepada para aparatur untuk dapat menata kerapian penyimpanan berkas administrasi serta untuk menambah papan informasi prosedur persyaratan kelengkapan administrasi yang dapat membantu masyarakat dalam pengurusan administrasi yang diperlukan.

\section{KESIMPULAN DAN SARAN}

Standar Pelayanan Pemerintah Kelurahan Kapuas Kiri Hilir sudah sesuai dengan Peraturan Pemerintah Nomor 17 Tahun 2018 tentang Kecamatan, dimana Kelurahan yang berkedudukan sebagai perangkat Kecamatan tentunya mengikuti acuan pedoman teknis yang ditetapkan oleh Kecamatan.Kompetensi Petugas Pelayanan belum optimal terutama dalam penguasaan IT, yang merupakan menjadi faktor berpengaruh dalam pelaksanaan tugas pelayanan administrasi Pemerintah Kelurahan Kapuas Kiri Hilir.Sarana dan Prasarana Pelayanan Kantor Kelurahan Kapuas Kiri Hilir perlu adanya penambahan fasilitas penunjang dalam penyelenggaraan pelayanan publik.

Saran yang diharapkan dapat menjadi informasi yang berguna bagi pihak-pihak yang berkepentingan, yaitu mengenai standar pelayanan Pemerintah Kelurahan Kapuas Kiri Hilir diharapkan untuk lebih meningkatkan sosialisasi mengenai kebijakan-kebijakan terbaru, supaya dapat diketahui dan dimanfaatkan oleh masyarakat. Diharapkan kompetensi petugas pelayanan yaitu Aparatur Pemerintah Kelurahan Kapuas Kiri Hilir perlu adanya pelatihan terutama dalam peningkatan kemampuan IT. Diharapkan fasilitas sarana dan prasarana pelayanan yang belum lengkap dapat ditingkatkan agar masyarakat lebih merasa nyaman ketika sedang melakukan kepengurusannya.

\section{DAFTAR PUSTAKA}


Arikunto, S. 2016. Prosedur Penelitian Suatu Pendekatan Praktik. Jakarta: Bina Aksara.

Dwiyanto, Agus. 2005. Mewujudkan Good Governance Melalui Pelayanan Publik. Yogyakarta: Gadjah Mada University Press.

Edy Sutrisno, 2016. Manajemen Sumber Daya Manusia. Cetak Ke 6. Jakarta : Pranada Media Group.

Hardiansyah .2011. Kualitas Pelayanan Publik. Yogyakarta: Gava Media.

Keban, T. Yeremias. 2008. Enam Dimensi Strategis Administrasi Publik, Konsep,Teori dan Isu. Yogyakarta : Gava Media

Moleong, J. Lexy. 2014. Metode Penelitian Kualitatif. Bandung : Remaja Rosdakarya.

Moenir, H.A.S. 2010. Manajemen Pelayanan Umum di Indonesia.Jakarta : Bumi Aksara.

Nurcholis, Hanif. 2007.Teori dan Praktik Pemerintahan dan Otonomi Daerah. Jakarta: PT Grasindo.

Sinambela. 2006. Reformasi Pelayanan Publik. Jakarta: PT Pertja.

Ratminto, \& Winarsih, A.S. 2016. Manajemen Pelayanan: Pengembangan Model Konseptual,Penerapan Citizen's
Charter dan Standar Pelayanan Minimal. Yogyakarta: Pustaka Pelajar. Sedarmayanti. 2011. Manajemen Sumber Daya Manusia, Reformasi Birokrasi dan Manajemen Pegawai Negeri Sipil. Cetakan Ke 5. Bandung : PT Refika Aditama

Siagian, P. Sondang. 2016. Manajemen Sumber Daya Manusia, Cetakan Ke-24. Jakarta : Bumi Aksara.

Sugiyono. 2008. Memahami Penelitian Kualitatif. Bandung : Alfabeta

Subarsono. 2008. Analisis Kebijakan Publik Konsep Teori dan Aplikasi. Yogyakarta: Pustaka Pelajar.

Pasolong, Harbani. 2008. Teori Administrasi Publik. Bandung: Alfabeta.

Widodo, Joko. 2008. Analisis Kebijakan Publik. Yogyakarta. Balairiung

Negara Republik Indonesia, 2009. Undang-Undang Nomor 25 tahun 2009 Tentang Pelayanan Publik

Negara Republik Indonesia, 2004. Undang-Undang Nomor 32 Tahun 2004 Tentang Pemerintah Daerah

Negara Republik Indonesia, 2003. Keputusan Menteri Pendayagunaan Aparatur Negara Nomor 63 Tahun 2003 Tentang Pedoman Umum Penyelenggaraan Pelayanan Publik. 